\title{
Spatial analysis and distribution modeling of Aconitum moldavicum in Ukrainian Carpathians and adjacent territories with special reference to the algorithm used
}

\author{
도. A. Novikov ${ }^{1,2}$, 이. Mitka ${ }^{3}$ \\ ${ }^{1}$ Department of Biosystematics and Evolution, State Museum of Natural History, National Academy of Sciences of Ukraine, Teatralna \\ str. 18, 79008 Lviv, Ukraine \\ 2 Department of Botany, Biology Faculty, Ivan Franko National University of Lviv, Hrushevskoho str. 4, 79004 Lviv, Ukraine; \\ novikoffav@gmail.com \\ ${ }^{3}$ Institute of Botany of Jagiellonian University, Botanical Garden, Jagiellonian University, Kopernika 27, 31-501 Kraków, Poland; \\ j.mitka@uj.edu.pl
}

Received: 20.01 .2020 | Accepted: 25.03 .2020 | Published: 30.06 .2020

\begin{abstract}
The paper aimed to conduct a comprehensive analysis of all available sources (including herbarium vouchers, publications, and datasets) on the exact distribution of Aconitum moldavicum in the Ukrainian Carpathians to build the maps modeling the species distribution in this region and adjacent territories.

Aconitum moldavicum is a Pancarpathian subendemic distributed widely along the Carpathian Mountain range and scattered out to some of the adjacent lowland territories. Surprisingly, A. moldavicum was found to be quite rare for the Transcarpathian Lowland, where it is represented only by A. moldavicum subsp. hosteanum. Just near the border with Slovakia, A. moldavicum subsp. moldavicum occurs in the Vygorlat Mts., while along with all other parts of the Vygorlat-Gutyn Carpathians it does not appear. However, both taxa, A. moldavicum subsp. moldavicum and A. moldavicum subsp. hosteanum, quite frequently appear in the Ciscarpathia and Volhynia-Podilia Highland together with their hybrid A. moldavicum nothosubsp. confusum.

Aconitum moldavicum nothosubsp. porcii and nothosubsp. simonkaianum occur exclusively in the Marmarosh region of the Ukrainian Carpathians, and probably A. moldavicum nothosubsp. porcii can also be re-find in the Chornohora. Presence of A. moldavicum nothosubsp. simonkaianum in the Volhynia-Podilia Highland seems to be doubtful because there are no other pieces of evidence despite the only voucher hosted at GJO herbarium. Moreover, other vouchers collected by B. Błocki from the same region were identified as belonging to A. moldavicum nothosubsp. hosteanum.

We used different algorithms of SDM (MaXent, BioClim, GARP, EnvDist, TIN, and IDW) to check the most sufficient and most closely representing a real distribution of $A$. moldavicum in the area studied. BioClim correctly pointed to the geographic centers of the species in the Carpathians, Volhynia-Podilia Highland, and in Polish Uplands. Traditionally applied algorithm MaxEnt underestimates the probability of occurrence of species in the area of confirmed presence and, at the same time, overestimates it in the area beyond the known extent of species occurrence. IDW algorithm showed similar results with MaxEnt and confirmed its potential suitability for SDM purposes.
\end{abstract}




\section{Introduction}

Aconitum moldavicum Hacq. is a Pancarpathian subendemic (Novikoff \& Hurdu, 2015; Kliment et al., 2016) and mountain species scattering out to adjacent lowlands (Zapałowicz, 1908; Mitka \& Kozioł, 2009; Misiak,2016). A. moldavicum sometimes is mentioned in red lists and assessments with different threat categories (Kricsfalusy \& Budnikov, 2003; Kadlečík, 2014; Cwener et al., 2016; Kozurak et al., 2017). However, it is not listed in the recent edition of IUCN Red List of Threatened Species due to the general lack of data on its taxonomy and chorology.

Aconitum moldavicum comprises five subspecies - subsp. moldavicum, subsp. hosteanum (Schur) Graebn. et P. Graebn., nothosubsp. simonkaianum (Gáyer) Starmühl., nothosubsp. porcii Starmühl., and nothosubsp. confusum (Grinț.) A. Novikov (Mitka, 2008; Novikov, 2017). The closest taxa revealing similar morphology and genetics are A. lasiostomum Besser and A. lycoctonum L. (including A. vulparia Spreng. and A. lasianthum (Rchb.) Simonk.) that also occur in adjacent to Carpathian Mts. regions (Utelli et al., 1999, 2000; Hong et al., 2017). They additionally contribute to the diversity of moldavicum group in the Carpathian region by producing putative hybrids (A. $\times$ triste (Rchb.) Gáyer and A. $\times$ baumgartenianum Simonk.) associated predominantly with Transilvania and SouthEastern Carpathians.

All five subspecies of A. moldavicum were already reported for the Ukrainian Carpathians and adjacent Volhynia-Podillya Highland (Novikoff \& Mitka, 2011; Mitka, 2008). However, precise mapping, which is crucial for accurate assessment of species distribution and further identification of threat category, was not performed before. Spatial analysis with modern species distribution modeling (SDM) algorithms, which also can be useful for evaluation of the general distribution of the species, was not realized too. Hence, here we represent our outcomes based on an analysis of 782 collection localities gathered from field surveys, herbarium collections, and published sources.

\section{Material and methods}

Spatial data was gathered from several sources, including 563 entries from direct analysis of herbarium vouchers, 130 entries from trusted published sources (Klimuk et al., 2006; Mitka, 2008), 75 entries from Karel Domin's Card Index hosted at the Institute of Botany in Bratislava, 14 entries from GBIF biodiversity database (GBIF, 2019), JACQ virtual herbarium (JACQ, 2019) and NHM DataPortal (Scott \& Smith, 2014). Only those entries that could be clearly identified as belonging to A. moldavicum were accepted for analysis. In case when there was a doubt or in the case whether it was impossible to identify subspecies clearly, such entries were accepted on a specific level without designation of infraspecific implication. For those entries that had no designated coordinates, approximate coordinates with annotated precision in meters were generated based either on the closest identified location or polygonal centroid. The final dataset was processed in QGIS 3.10.1 (QGIS Development Team, 2020). In QGIS, an additional mesoregional layer (accordingly to Novikov \& Hurdu (2017) with recent updates) and the DEM (Digital Elevation Model) layer were associated with this dataset.

SDM was performed independently in Maxent 3.4.1 (Philips et al., 2006; Philips \& Dudik, 2008), applying online facilities of Lifemapper LmSDM (i.e., BiotaPhy web client) (Williams et al., 2017), and in QGIS 3.10.1 environment. For modeling in Maxent software, we used SRTM 90m DEM layer downloaded from CGIAR-CSI (Jarvis et al., 2008). Maxent software applies same-called unique algorithm, which is considered one of the most reliable for modeling of distribution on poorly known areas and with a small sample size (Hernandez et al., 2006, 2008). Maxent software requires precise preparation of projection layers with the same resolution and covering area, which can be difficult for inexperienced users with basic skills. For modeling in Lifemapper we used 'Worldclim 1.4, Soil, SpatialDistance' model and applied BioClim, GARP, EnvDist and MaxEnt (openModeller implementation) algorithms, which are also usually applied for rich samples (Stockwell \& Peterson, 2002; Beaumont et al., 2005; Passos \& Rebello, 2016). SDM in QGIS 

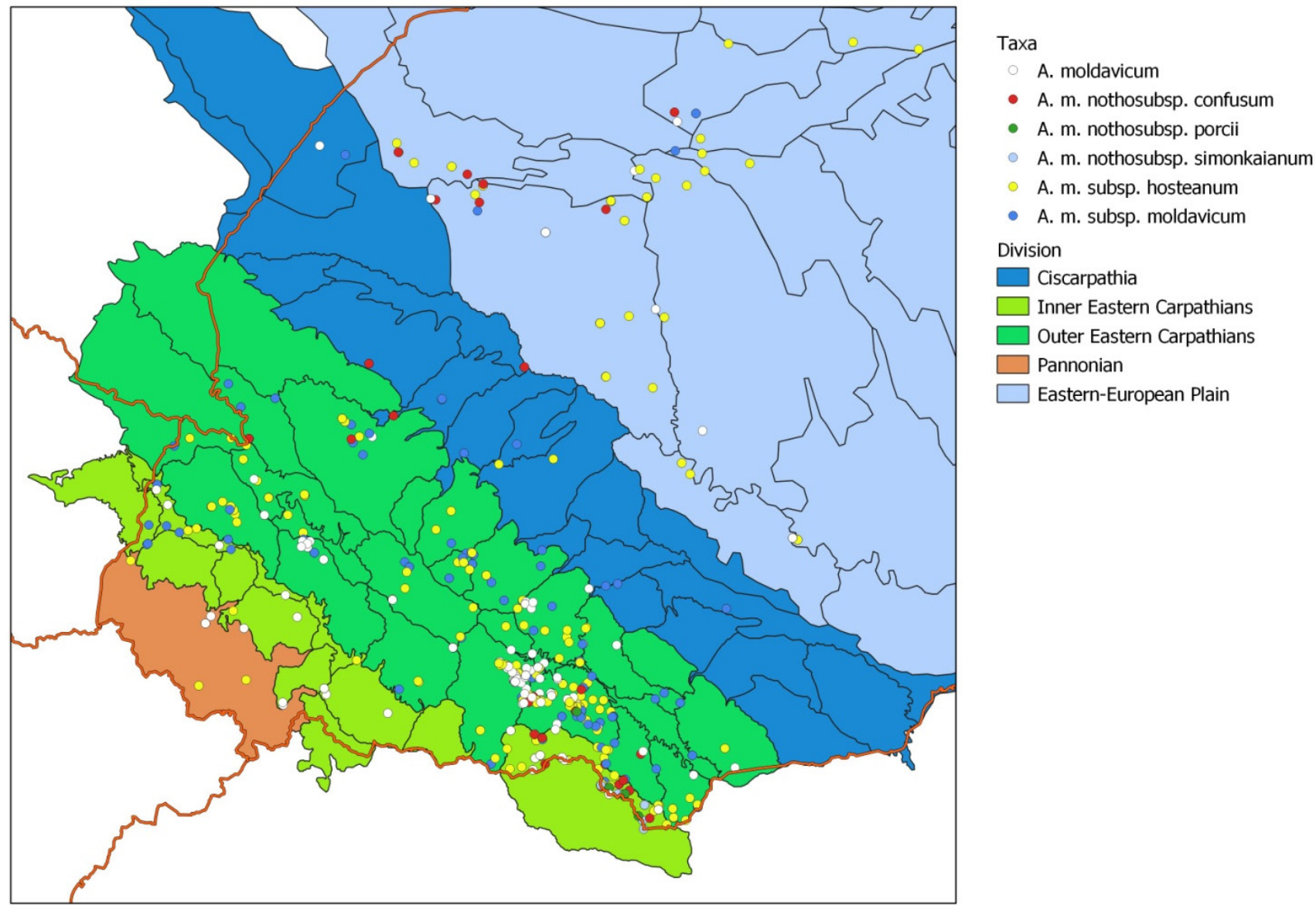

Figure 1. The original distribution of Aconitum moldavicum within the Ukrainian Carpathians and adjacent regions basing on all available data (field surveys, herbarium vouchers, published observations and other sources).

was performed by TIN and IDW interpolation based on a number of occurrences calculated for each geomorphologic mesoregion. TIN and IDW usually are not applied for niche modeling, because they are not prediction algorithms in a strict sense and work only with continuous data. However, it was proved that these powerful spatial interpolation methods can be useful for modeling of species richness (Tapia-Silva et al., 2015), and, as a result, can also be applied for preliminary analysis of a potential area of occupation by organisms (Gomes et al., 2018).

\section{Results and discussion}

\section{Spatial Distribution}

Our investigations revealed that A. moldavicum is scattered over Ukrainian Carpathians unevenly - with a higher concentration in the SE part, including Svydovets, Chornogora, and Marmarosh massifs. (Figs. 1 \& 2). The number of registered occurrences of A. moldavicum in subcarpathian regions (i.e., Transcarpathia and Ciscarpathia) is much lower. However, another local center of distribution of A. moldavicum is located in the Opillia Highland, a mesoregion of the Volhynia-Podilia Highland, situated on $\mathrm{NE}$ from the Carpathian ridge. The presence of a high number of occurrences in these regions correlates with subspecific diversity. In particular, the Marmarosh Mts. host all five subspecies of A. moldavicum, while the Chornohora Mts. and the Opillia Highland represents four and three subspecies, respectively.

Chornohora and Marmarosh are the only regions with confirmed presence of A. moldavicum nothosubsp. porcii. Most of the occurrences of this subspecies lie within Marmarosh mesoregion, and only one voucher from 1926 is cited for Chornohora.

Another hybrid, A. moldavicum nothosubsp. simonkaianum occurs only in the Marmarosh Mts. (in those part that is usually mentioned in publications as the Chyvchyny Mts.). In Mitka (2008) there is mentioned voucher 

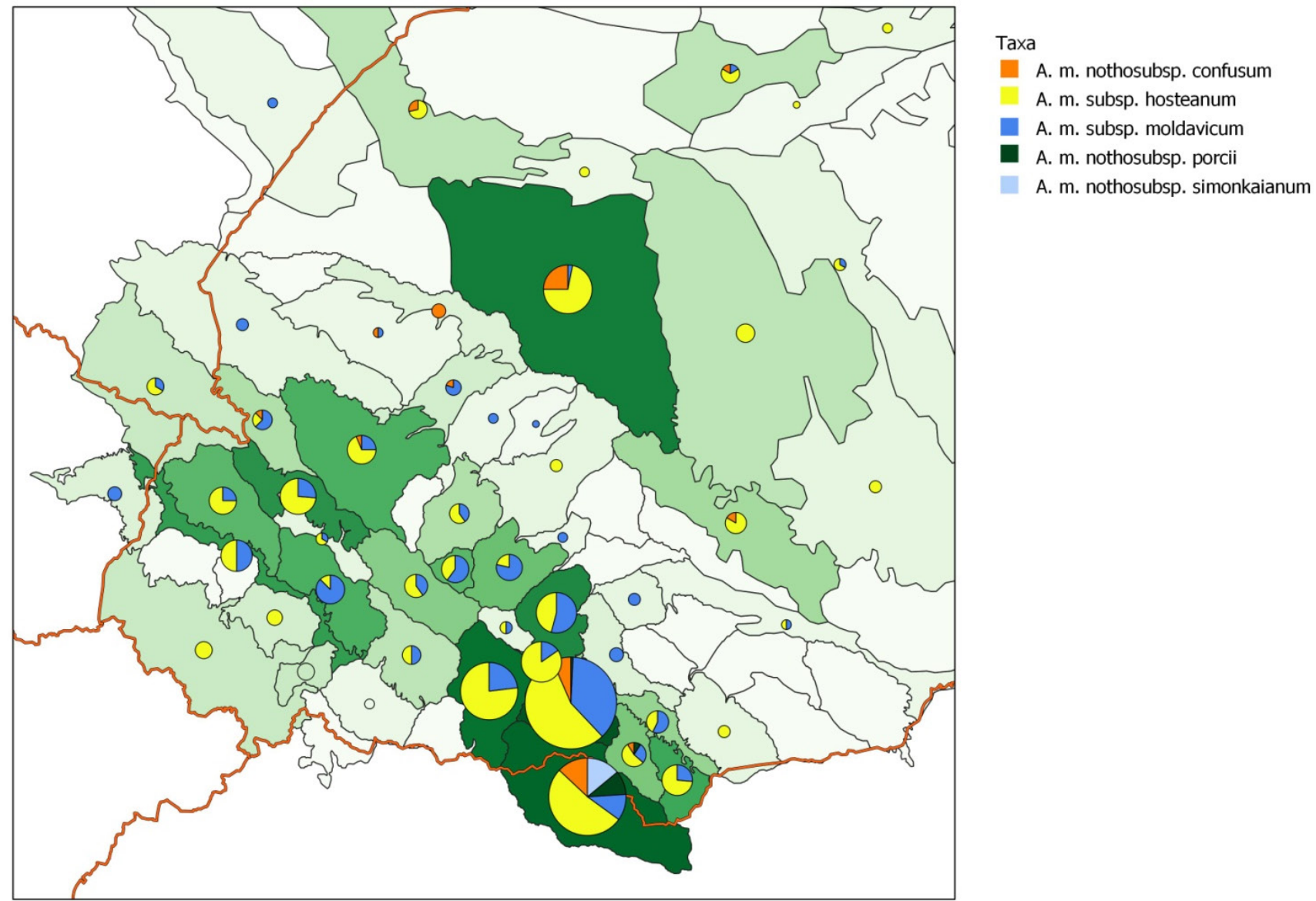

Figure 2. Proportional distribution of Aconitum moldavicum within the Ukrainian Carpathians and adjacent regions (the darkest color of mesoregion, the higher number of observations).

of A. moldavicum nothosubsp. simonkaianum preserved in the herbarium GJO of Universalmuseum Joanneum in Graz, Austria. However, after analysis of other vouchers collected by the same collector (B. Błocki) from the same region and at the same period, we could suggest that it likely belongs to A. moldavicum nothosubsp. hosteanum that is quite frequent in the Volhynia-Podilia Highland.

One of the parental taxa of A. moldavicum nothosubsp. simonkaianum is A. lasiostomum (= A. rogowiczii Wissjul.), which mostly occurs in the Steppe and Forest-Steppe regions of Ukraine (Dobrochaeva et al., 1987; Tzvelev, 2001). However, one locality of A. lasiostomum is cited from the Opillia Highland (between villages Ivanivka and Podusilna, Lviv region) and one more locality of A. rogowiczii from the Holohory (Kremenets town, Ternopil region) (Wissjulina, 1953). Hence, we cannot reject the possibility of the presence of A. moldavicum nothosubsp. simonkaianum in the VolhyniaPodilia Highland, at least in the past.
Aconitum moldavicum nothosubsp. confusum, resulting from hybridization between subsp. moldavicum and subsp. hosteanum, also shares the same distribution with A. moldavicum nothosubsp. hosteanum, including the Volhynia-Podilia Highland and the Poland Uplands. Interesting that participation of A. moldavicum nothosubsp. confusum in the Opillia Highland and neighboring regions is relatively high (about $25 \%$ ), while in separated mesoregions of the Carpathian Mts. it does not exceed $13 \%$. Hence its presence reveals that either parental taxa still could be discovered in this region or they were distributed there before. In general, A. moldavicum subsp. moldavicum and A. moldavicum subsp. hosteanum remain to dominate both in the Carpathians and adjacent lowlands.

Both hybrids, A. moldavicum nothosubsp. simonkaianum and A. moldavicum nothosubsp. porcii, demonstrate distribution pattern slightly different from all other subspecies of A. moldavicum. Most occurrences of these two endemic taxa (Mitka, 2008) are 
concentrated in the Marmarosh Mts. region, which is considered one of the local centers of endemics' distribution in the Ukrainian Carpathians (Tasenkevich, 2014) within the main Pokuttya-Marmarosh center of endemism (Pawłowski, 1970).

The Svydovets, Chornogora, and Marmarosh Mts. are among the highest regions of the Ukrainian Carpathians and differ by the highest diversity of flora (Chopyk, 1976; Malynovskiy, 1991; Tasenkevich, 2003). In particular, Chornogora represents the highest diversity of genus Aconitum in the Ukrainian Carpathians (Novikoff et al., 2016). However, A. moldavicum is not related to high altitudes so much. In the Ukrainian Carpathians, it mostly occupies localities from submontane to upper montane belt (roughly 650-1400 m a.s.l.). Sometimes it occurs in the subalpine belt (up to 1850 $\mathrm{m}$ a.s.l.), and only occasionally can be found in the alpine belt. Therefore its correlation with high-altitudinal mesoregions has rather an inexplicable nature.

Surprisingly, A. moldavicum is quite rare for the Transcarpathian Lowland and adjacent regions of the Carpathian range. Here it seems to be represented only by A. moldavicum subsp. hosteanum. Just near the border with Slovakia, A. moldavicum subsp. moldavicum occurs in the Vygorlat Mts., while along with all other parts of the Vygorlat-Gutyn Carpathians it does not appear.

Aconitum moldavicum prefers wet and semi-shaded locations, especially often it is distributed in the forests along the streams that make natural corridors of its propagation (Mitka, 2003; Novikoff et al., 2016). However, it also can be found in relatively dry and open places, where it differs by short and compact shoot, lower number of flowers, and slightly branched inflorescences. The plant demonstrates the widest ecological amplitude and very often can be found in semiruderal and disturbed places along the roads, in mountain villages, in forest fringes, etc. However, local populations of A. moldavicum are usually small and represented by few clone plants that appeared in the result of rhizome fragmentation. Seed propagation in A. moldavicum has not been investigated yet, but our preliminary conclusion is that it plays a secondary role.

In the Ukrainian Carpathians A. moldavicum can be often found in very different habitats including vegetation communities of lower elevations like Fagion sylvaticae, Tilio-Carpinetum, Dentario glandulosaeFagetum, Alnetum incanae, Rubetum idaei and Scirpo sylvatici-Caricetum brizoidis, as well as communities of higher altitudes like Chaerophylletum aromaticum, Stellario nemorum-Alnetum glutinosae, PulmonarioAlnetum viridis, Juniperetum sibiricae, Calthetum laetae, Arunco-Doronicetum austriaci and Ranunculo platanifoliiAdenostyletum alliariae (Mitka \& Kozioł, 2009; Novikoff et al., 2016; Kobiv, 2018). Both subspecies, A. moldavicum subsp. moldavicum and A. moldavicum subsp. hosteanum share the same ecological and vegetation conditions and even can be found in mixed populations together with A. moldavicum nothosubsp. confusum. However, the preferences of A. moldavicum nothosubsp. simonkaianum and A. moldavicum nothosubsp. porcii require clarification. Investigations on Aconitum habitat preferences, including soil and vegetation analysis, were carried out before (Novikoff et al., 2016; Novikoff, 2016), but still seek information from a more full area.

\section{Species distribution modeling}

Firstly we applied the single elevation parameter for SDM in original Maxent software to stress it as a critical factor for the distribution of A. moldavicum. This was done to eliminate side-effecting factors and to reveal any potential influence of the elevation on the distribution of this species. The elevation is frequently reported as one of the key factors, affecting the distribution of plant taxa, especial endemic, in different mountain regions (Vetaas \& Grytnes, 2002; Wang et al., 2003; Singh et al., 2007; Subedi et al., 2015), including Carpathian Mountains (Tsaryk et al., 2003; Piękoś-Mirkowa \& Mirek, 2009; Kyyak et al., 2016; Mráz et al., 2016). In particular, elevation has confirmed influence on the origination of genetic diversity and speciation in mountain plants (Thiel-Egenter et al., 2009), including Aconitum representatives (Hardin, 1964; Sutkowska et al., 2013; Chapagain et al., 2019). In our preliminary investigations, we have also suggested that elevation may be the factor determining the structure of the inflorescence in A. variegatum L. (Novikoff, 2009). Similarly, it was found that elevation in the context of 
climate changes influences on the phenology of A. heterophyllum Wall. (Gaira et al., 2011). Hence, here we tried to separate elevation from other factors to analyze its influence on the distribution patterns of A. moldavicum independently. Later additional algorithms (i.e., BioClim) covering other factors were also applied within Lifemapper online service to obtain more complete results.

We generated maps of the prospective distribution of A. moldavicum basing on four datasets: (A) all available occurrence data; (B) data just about precise occurrence (only from mountain regions); (C) combination of precise localities from mountains with estimated localities from lowlands; (D) estimated localities from lowlands only (Fig. $3 \mathrm{~A}-\mathrm{D}$ ). In a case of the full dataset, the main distribution was concentrated in the regions with the highest altitude. In contrast, in the lowlands, the prognostic distribution does not exceed $23 \%$ (with relatively low AUC $=0.797$ ). Chornohora, Svydovets, and Gorgany regions, at the same time, are among the highest and very popular for floristic surveys. Moreover, many coordinates were obtained from approximate supposition and could point to higher localities than they are. To avoid artificial amplification of highmountain regions, we analyzed localities with only precisely known coordinates and elevation respectively. In this case, highmountain regions were still modeled as the most appropriate for the distribution of A. moldavicum, while lowlands were illuminated from analysis and demonstrated prognostic distribution below $8 \%$. AUC value in such a case was 0.919 , which confirms the high reliability of obtained prediction (Jiménez-Valverde, 2012). Finally, we combined an almost equal number of localities with precise coordinates with those with approximate coordinates, and still, the highest regions remained to be the most suitable. As a result of such a combination, the lowland regions obtained up to $54 \%$ of prediction; however, the AUC value was the lowest -0.713 . As a result of the analysis, the dataset of exclusively approximate localities from lowlands, mountains were totally omitted but predicted distribution on lowlands did not oversize $77 \%$ with relatively low accuracy $($ AUC $=0.766)$.

Relatively low accuracy of obtained models in case of analysis of (C) and (D) datasets together with high accuracy obtained during analysis of dataset (B) (Fig. 3) indicate that altitude is not a key factor for the distribution of A. moldavicum in lowland regions. Nevertheless, still, elevation seems to be among essential factors affecting the distribution of A. moldavicum in the mountain region of the Ukrainian Carpathians.

In lowlands, the elevation changes not so dramatically as in the mountains. In the mountains, the elevation changes are much frequent and therefore require more precise identification of coordinates. The application of data with approximately estimated coordinates in the mountains could be risky. However, our analysis showed almost consistent results both for precise data and the combination of precise and approximate data. Hence we can assume that such mixed datasets can be effectively applied for SDM. From another side, data cleaning before analysis is a necessary process that should be conducted by specialists that are familiar with ecological preferences of analyzed taxa (Maldonado et al., 2015; Gomes et al., 2018). Splitting of datasets on smaller portions also can be useful for niche modeling of taxa distribution in heterogeneous areas (Stockwell \& Peterson, 2002).

Lifemapper online tool provides an excellent opportunity for modeling species distribution, including the number of layers and algorithms, as well as on-flight export of data from GBIF. We applied four main algorithms (Fig. 4) that showed utterly different results. MaxEnt prediction was close to that we obtained using original Maxent software with strong attribution to high-mountain regions of the Ukrainian Carpathians. However, lowland regions of the VolhyniaPodilia Highland obtained much higher prediction (Fig. 4 A). On a large scale, MaxEnt algorithm also showed a higher prediction of the distribution of A. moldavicum along all the Carpathian Mts. range and even extension of its areal to the Apuseni in Romania, the Sudety Mts. in the Czech Republic and the Austrian Alps (Fig. 5 A). Outside the Carpathians, such modeled distribution of A. moldavicum has only theoretical value since it is the Carpathian's subendemic. BioClim algorithm, in general, demonstrated quite a low level of $50 \%$ prediction, evenly scattered along the Ukrainian Carpathians and covered almost all 

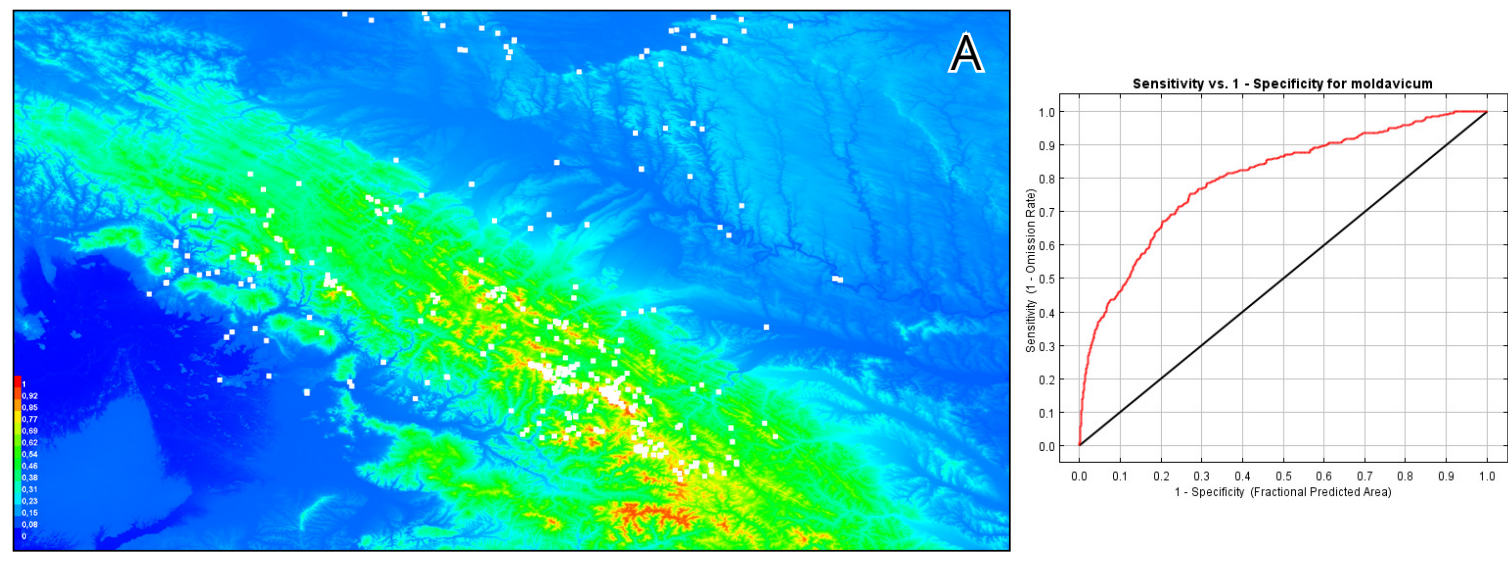

Training data (AUC $=0.797)$ :
dom Prediction (AUC $=0.5)$

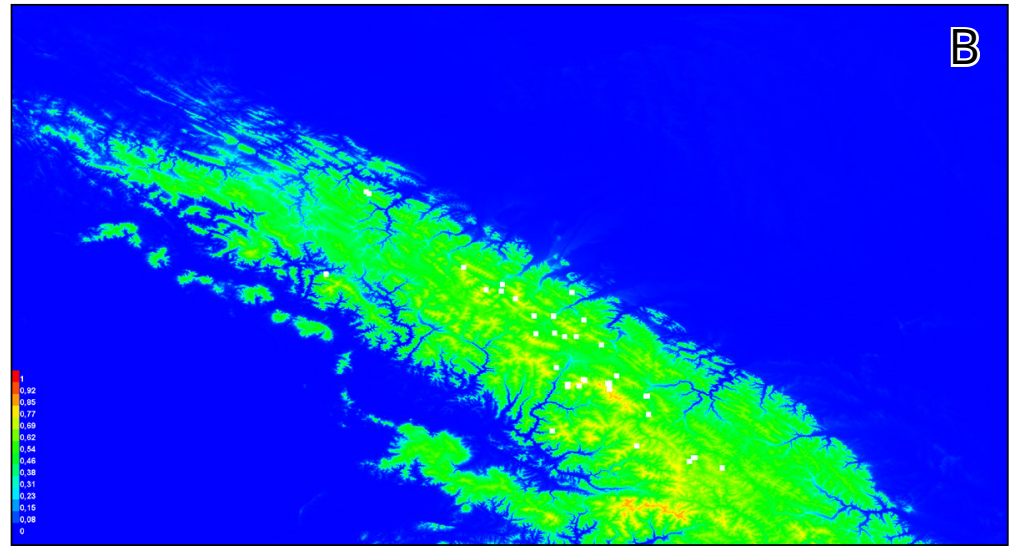

D
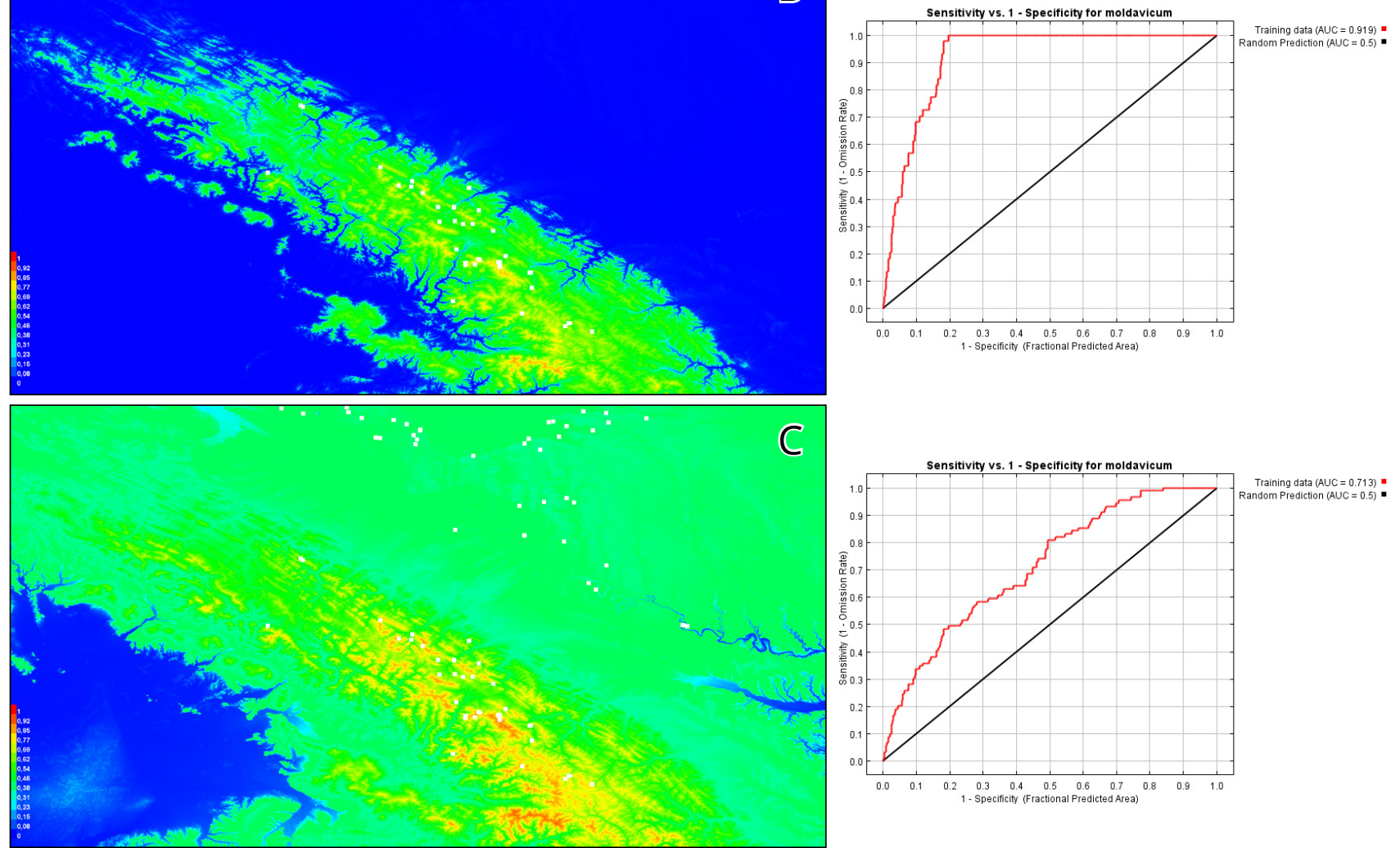

C
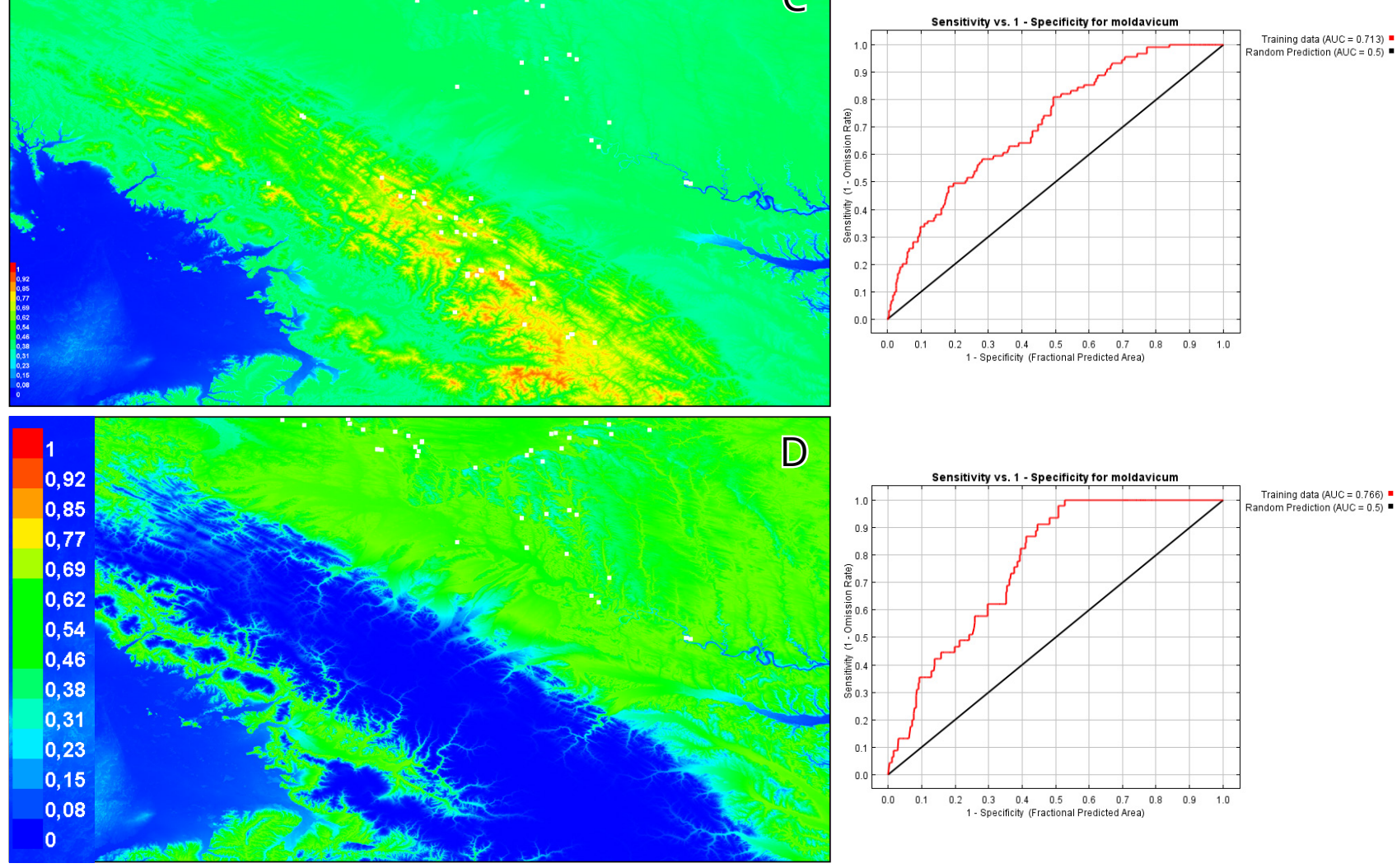

Figure 3. Maxent prediction of Aconitum moldavicum distribution in the Ukrainian Carpathians and adjacent regions basing from elevation. Color scale indicates occurrence prediction. Graphs show AUC values for each of the predictions (the higher AUC the highest reliability of the model obtained). Models are based on all available distribution data (A); exclusively precise data obtained from direct observations in mountain regions (B); the combination of precise localities from mountains with estimated localities from lowlands (C); estimated localities from lowlands only (D). 

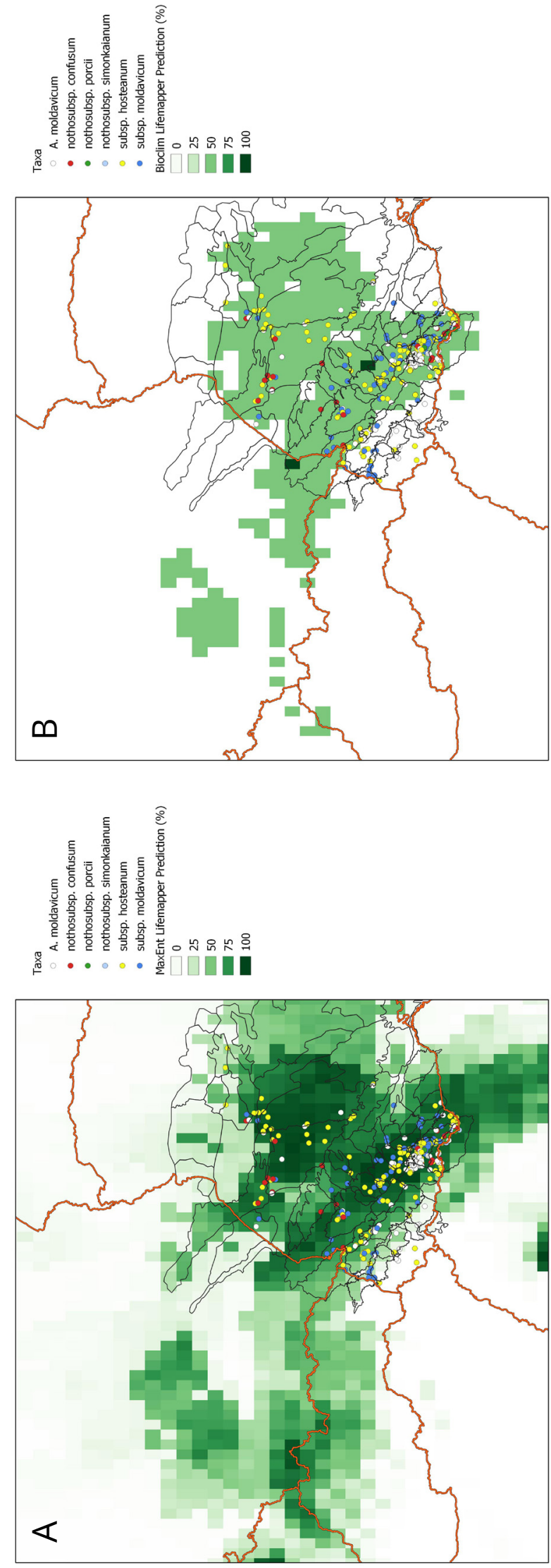
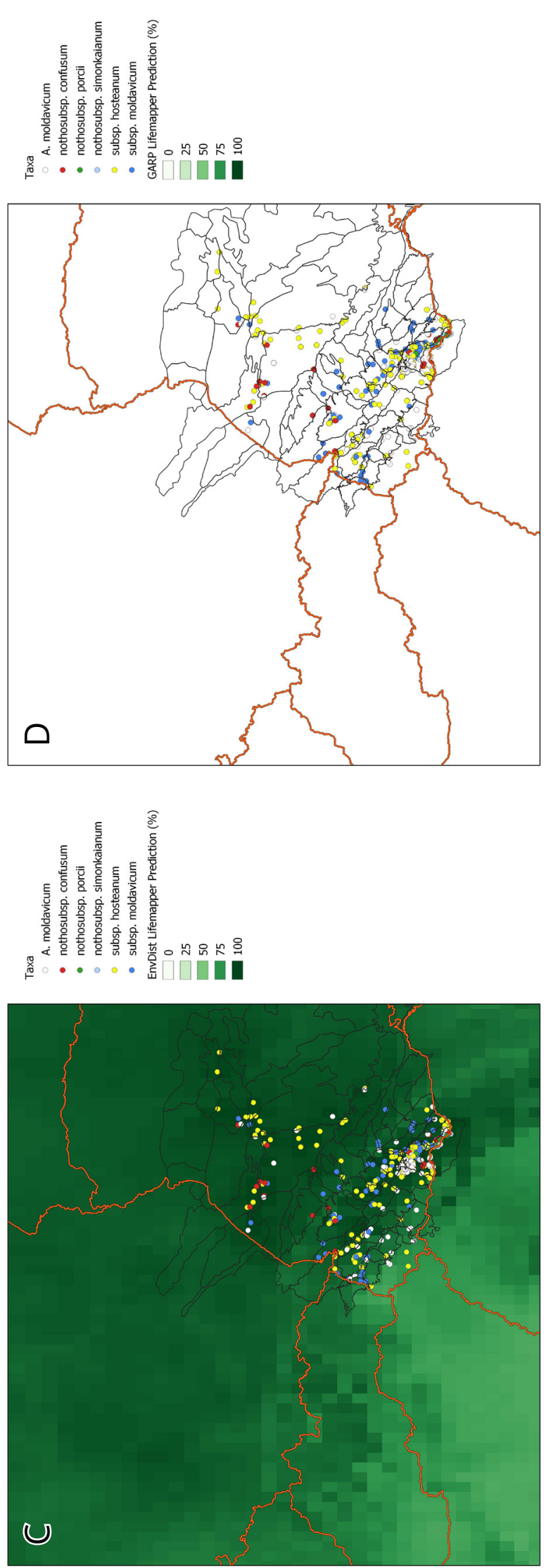

है

망

뒁

屯는

出

ᄃ욜

nod

高苟

$\stackrel{0}{\circ} . \overline{0}$

동 ज

음

$\stackrel{\circ}{0}$

동 $\frac{\oplus}{\frac{\pi}{n}}$

음

ช ธ

든

는 은

흠

紊高

는

نे $\frac{\sqrt{0}}{000}$

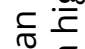

. $\frac{\pi}{\sigma}$

亲

오음

드응

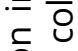

음

근 $\frac{2}{\frac{1}{\tau}}$

㝕

응

$\varepsilon F$

ㅁ.

훙

का

ही

ह 는

옹

어

㟧

들 틀

능 응

닌

舟

这更

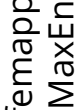

$\stackrel{ \pm}{1}$

ن

वें

니응

눈 음 

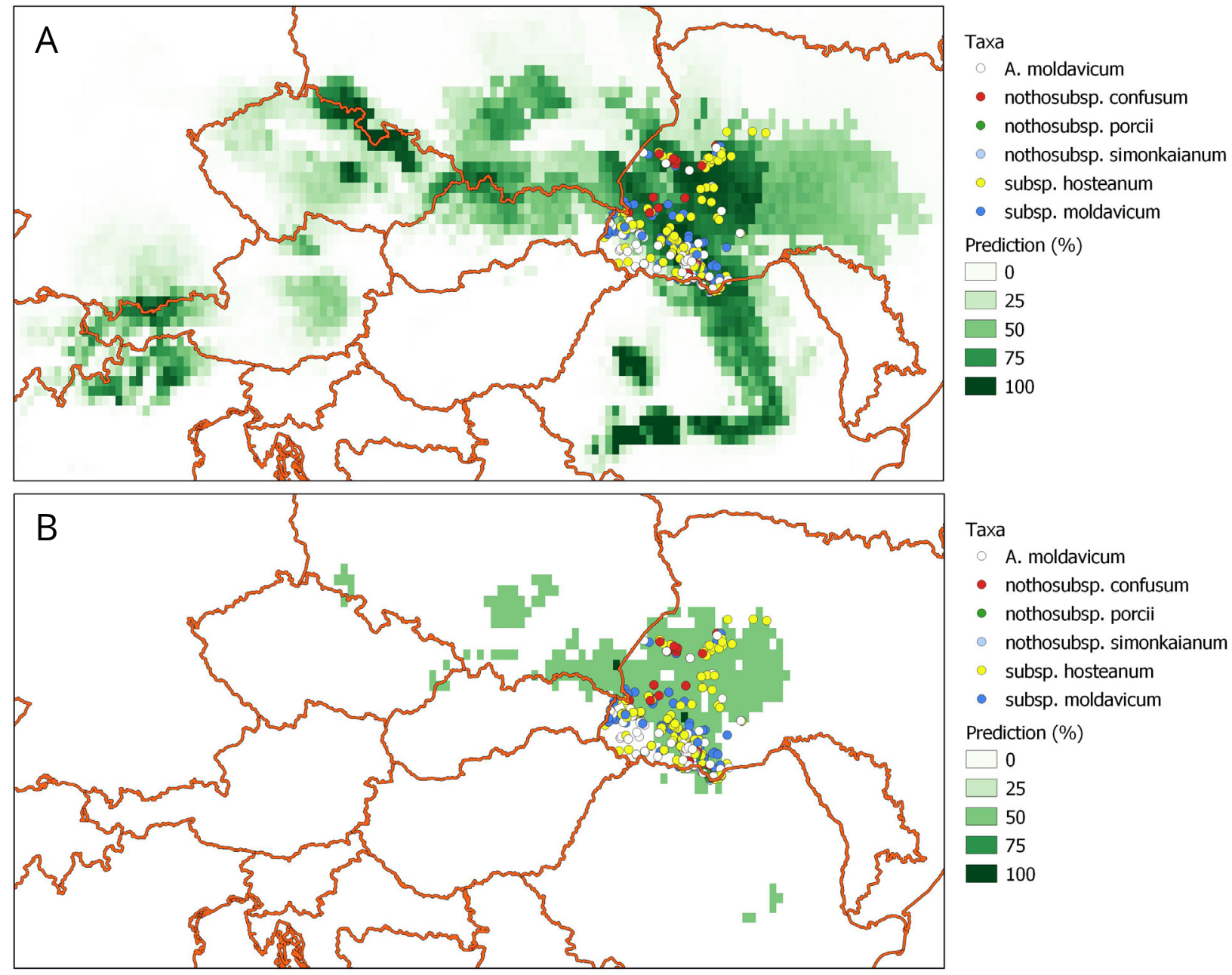

Taxa

- A. moldavicum

- nothosubsp. confusum

- nothosubsp. porcii

- nothosubsp. simonkaianum

- subsp. hosteanum

- subsp. moldavicum

Prediction (\%)
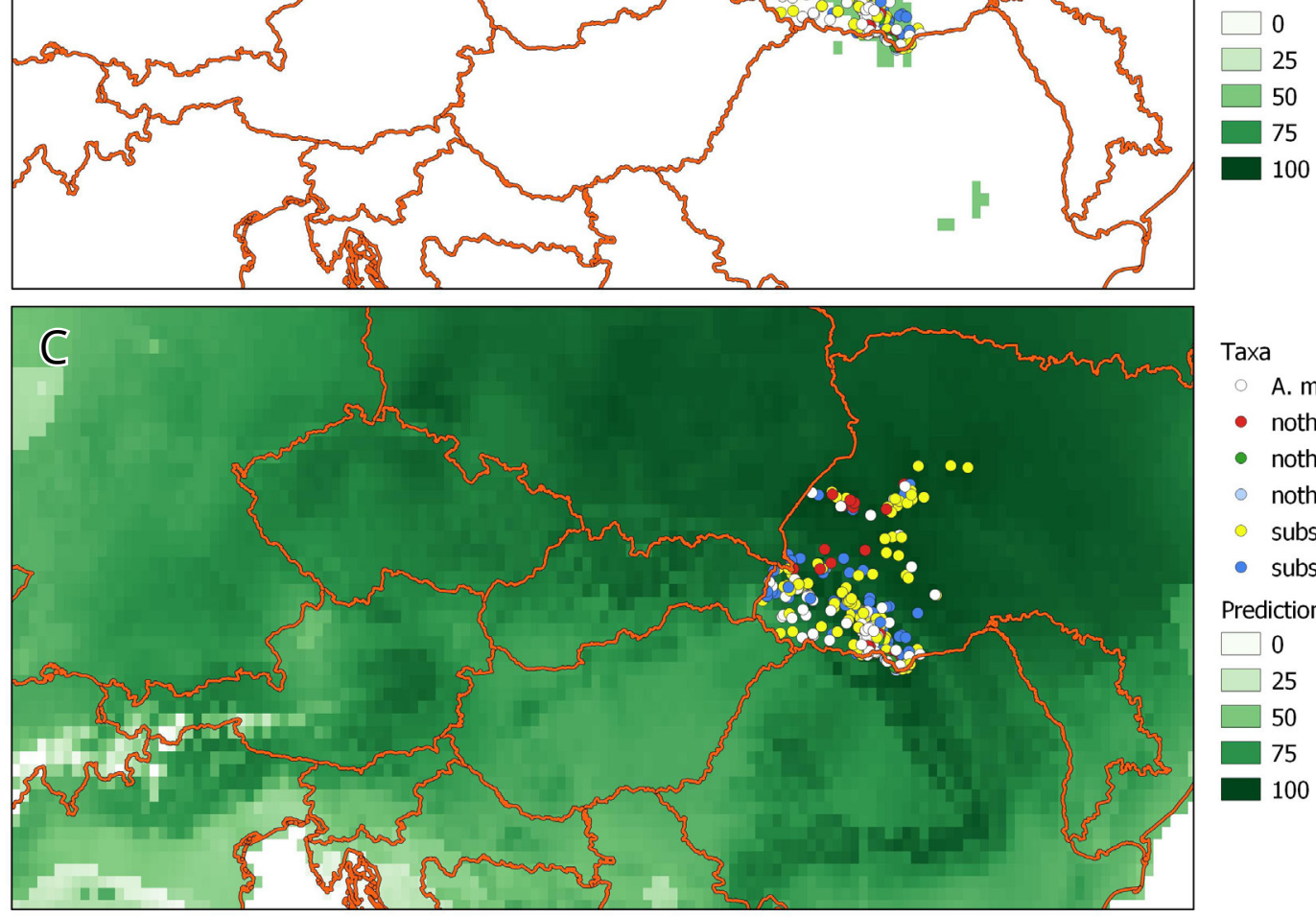

Taxa
A. moldavicum
- nothosubsp. confusum
- nothosubsp. porcii
- nothosubsp. simonkaianum
subsp. hosteanum
- subsp. moldavicum

Prediction (\%)

$\square 0$

$\square 25$

$\square 50$

75

100

Figure 5. Lifemapper prediction of Aconitum moldavicum distribution within a wider range basing on different algorithms applied: A - MaxEnt, B - BioClim, C - EnvDist. The darkest color indicates a higher prediction on the site. Points indicate known locations within the Ukrainian Carpathians and adjacent regions.

Volhynia-Podilia Highland (Fig. 4 B). However, on a large scale, BioClim predicted distribution of A. moldavicum predominately in the Eastern Carpathians with scattering in the Western Carpathians, and slight distribution to the South Carpathians (Fig. 5 B). These results the closest correspond to the real distribution of A. moldavicum, and especially interesting is its prediction for the Polish Uplands, where is one of the local lowland centers of the species distribution (Szafer, 1930; Zając, 1996; Mitka, 2008; Mitka \& Kozioł, 2009; Mitka et al., 2013). 
Another two algorithms of Lifemapper, EnvDist, and GARP did not show any acceptable results. EnvDist prediction covered almost all terrestrial parts of Europe (Figs. 4 C \& 5 C). Sites predicted by EnvDist also sporadically appeared in Northern America (from Alaska Range through Rocky Mts. and to Appalachian Mts.), North China Plain, Korea, Japan, and Kamchatka. GARP did not generate any prediction at all (Figs. 4 D).

Finally, for SDM we applied in-build interpolation algorithms TIN and IDW from QGIS 3 package (Fig. 6). Both TIN and IDW are factor-unrelated algorithms and predict distribution exclusively basing on a calculation of distances from extant localities. This makes them unacceptable for prediction in cases with low data coverage but still can be useful for preliminary estimation of the distribution of species, especially those with continuous ranges. Moreover, traditionally applied algorithms like MaxEnt can underestimate the probability of occurrence of species in the area of confirmed presence and, in the same time, overestimate it in the area beyond the known extent of species occurrence (Fitzpatrick et al., 2013; Gomes et al., 2018). In our case, both methods (TIN and IDW) showed the highest prediction of A. moldavicum in the Chornohora Mts., with slightly less concentration in surrounding mesoregions - Marmarosh, Svydovets, Gorgany and partly in Gryniava. IDW also predicted extension of A. moldavicum areal to the Romanian Carpathians, with the highest concentration in the Maramures and Rodna Mts. Both methods also confirmed the presence of a semi-isolated center of distribution of A. moldavicum in the Opillia Highland. The general similarity of obtained results from IDW and MaxEnt confirmed the suitability of IDW application for SDM purposes.

\section{Conclusions}

Taking into count all results, we can assume that the occurrence of A. moldavicum is not dependent on elevation in lowland regions. However, within the Carpathian Mts., it still plays an important role. Hence, further precise investigations with detailed analysis of other ecological data harvested directly from populations are required. Nevertheless, the distribution of A. moldavicum in the Ukrainian Carpathians is mainly related to such highest mesoregions as Chornohora, Marmarosh, Svydovets, and Gorgany. While in the Volhynia-Podilia Highland it is mostly concentrated in the Opillia Highland; where is, probably, located its local center of the distribution.

Analyzing prediction models and known distribution, we can also confirm that A. moldavicum (including subsp. moldavicum, subsp. hosteanum, and nothosubsp. confusum) is a Pancarpathian subendemic. A. moldavicum nothosubsp. simonkaianum is an Eastern-Carpathian (sub)endemic and A. moldavicum nothosubsp. porcii is a SouthEastern Carpathian - Apuseni endemic. Both, A. moldavicum nothosubsp. simonkaianum and A. moldavicum nothosubsp. porcii have extremely limited distribution in the Ukrainian Carpathians (Marmarosh and probably Chornohora Mts.) and require protection.

IDW algorithm demonstrated good results of distribution analysis and prediction together with MaxEnt and, therefore, can be applied for in niche modeling. This is concordant with recently published results of Gomes et al. (2018). BioClim algorithm resulted in slightly different outcomes that do not allow to evaluate the level of prediction of A. moldavicum among different mesoregions, but the better delimited general range of the species. Hence, we believe that any of the mentioned algorithms cannot be applied separately. Only a combination of different SDM algorithms can result in appropriate modeling.

\section{Acknowledgements}

This investigation resulted from long-term work within several grants obtained by AN, including a stipend of Scholarship of the Queen Jadwiga Fund of the Jagiellonian University (2009), Rufford's small grant 16667-1 (2015-2016) and Rufford's small grant 21313-2 (2017-2018), a grant of the National Scholarship Program of the Slovak Republic (2018), as well as the award of Lviv Researchers System (2019). AN cordially thanks to all supporting bodies and colleagues that helped in the realization of this study. 

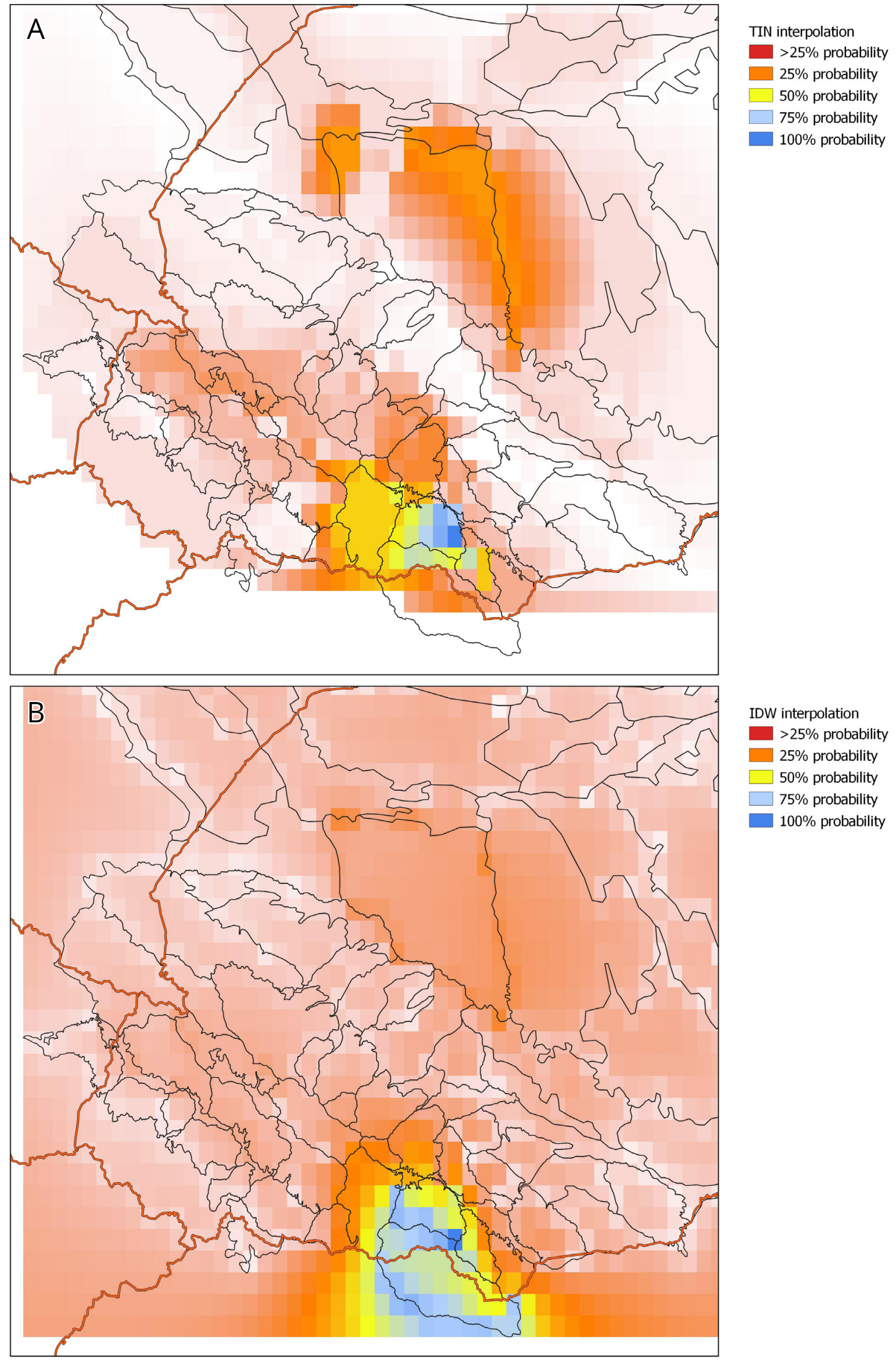

Figure 6. TIN (A) and IDW (B) interpolations applied for SDM purposes. Prediction of Aconitum moldavicum distribution in the Ukrainian Carpathians and adjacent regions based exclusively on known localities. 


\section{References}

Beaumont, L., Hughes, L., \& Poulsen, M. (2005). Predicting species distributions: use of climatic parameters in BIOCLIM and its impact on predictions of species' current and future distributions. Ecological Modelling, 186(2), 251-270. https://doi.org/10.1016/j.ecolmodel.2005.01.030

Chapagain, D. J., Meilby, H., \& Ghimire, S. K. (2019). Plant density and life history traits of Aconitum spicatum in North-Central Nepal: effects of elevation and anthropogenic disturbances. PeerJ, 7, e7574. https://doi.org/10.7717/peerj.7574

Chopyk, V. I. (1976). High-mountain flora of Ukrainian Carpathians. Kyiv: Naukova Dumka. (In Ukrainian)

Cwener, A., Michalczuk, W., Krawczyk, R. (2016). Red list of vascular plants of the Lublin Region. Annales Universitatis Mariae Curie-Sklodowska, sectio C - Biologia, 71(1), 7-26. https://doi. org/10.17951/c.2016.71.1.7

Dobrochaeva, D. N., Kotov, M. I., Prokudin, Y. N., Barbarych, A. I., Chopyk, V.I., Protopopova, V. V., Moroziuk, S. S., Dubovyk, O. N., Zyman, S. N., Sheliag-Sosonko, Y. R., Miakushko, T. Y., Zaverukha, B. V., Katina, Z. F., Skrypnyk, N. P., Kritskaya, L. I., Lypa, A. L., Mrinskiy, O. P., Alekseyev, Y. Y., Skvortsov, A. K., ... Ornst, E. Y. (1987). Identification key of higher plants of Ukraine. Kiyv: Naukova Dumka. (In Russian)

Fitzpatrick, M. C., Gotelli, N. J., \& Ellison, A. M. (2013). MaxEnt versus MaxLike: empirical comparisons with ant species distributions. Ecosphere, 4(5), 1-15. https://doi.org/10.1890/ ES13-00066.1

Gaira, K. S., Dhar, U., \& Belwal, O. K. (2011). Potential of herbarium records to sequence phenological pattern: a case study of Aconitum heterophyllum in the Himalaya. Biodiversity and Conservation, 20, 2201. https://doi.org/10.1007/ s10531-011-0082-4

GBIF. (2019, 8 September). GBIFoccurrence download. https://doi.org/10.15468/dl.olucaj

Gomes, V. H. F., ljff, S. D., Raes, N., Amaral, I. L., Salomão, R. P., Coelho, L. D. S., Matos, F. D. D. A., Castilho, C. V., Filho, D. D. A. L., López, D. C., Guevara, J. E., Magnusson, W. E., Phillips, O. L., Wittmann, F., Carim, M. D. J. V., Martins, M. P., Irume, M. V., Sabatier, D., Molino, J. F., ... Ter Steege, H. (2018). Species distribution modelling: contrasting presenceonly models with plot abundance data. Scientific Reports, 8, 1003. https://doi.org/10.1038/s41598017-18927-1

Hardin, J. (1964). Variation in Aconitum of Eastern United States. Brittonia, 16(1), 80-94.
Hernandez, P. A., Graham, C. H., Master, L. L., \& Albert, D. L. (2006). The effect of sample size and species characteristics on performance of different species distribution modelling methods. Ecography, 29, 773-785. https://doi. org/10.1111/j.0906-7590.2006.04700.x

Hernandez, P. A., Franke, I., Herzog, S. K., Pacheco, V., Paniagua, L., Quintana, H. L., Soto, H. A., Swensen, J. J., Tovar, C., Valqui, T. H., Vargas, J., \& Young, B. E. (2008). Predicting species distributions in poorly-studied landscapes. Biodiversity and Conservation 17, 1353-1366. https://doi.org/10.1007/s10531007-9314-z

Hong, Y., Luo, Y., Gao, Q., Ren, C., Yuan, Q., \& Yang, Q.-E. (2017). Phylogeny and reclassification of Aconitum subgenus Lycoctonum (Ranunculaceae). PLOS One, 12(1), e0171038. https://doi. org/10.1371/journal.pone.0171038

JACQ. (2019, 8 September). JACQ virtual herbarium. Retrieved from https://herbarium.univie.ac.at/ database/index.php

Jarvis, A., Reuter, H. I., Nelson, A., \& Guevara, E. (2008). Hole-filled seamless SRTM data V4. International Centre for Tropical Agriculture (CIAT). Retrieved from http://srtm.csi.cgiar.org

Jiménez-Valverde, A. (2012). Insights into the area under the receiver operating characteristic curve (AUC) as a discrimination measure in species distribution modelling. Global Ecology and Biogeography, 21, 498-507. https://doi. org/10.1111/j.1466-8238.2011.00683.x

Kadlečík, J. (2014). Carpathian Red List of forest habitats and species. Carpathian list of invasive alien species (draft). Banská Bystrica: Štátna ochrana prírody Slovenskej republiky.

Kliment, J., Turis, P., \& Janišová, M. (2016). Taxa of vascular plants endemic to the Carpathian Mts. Preslia, 88, 19-76.

Klimuk, Y. V., Miskevych, U. D., Yakushenko, D. M., Chorney, I. I., Budzhak, V. V., Nyporko, S. O., Shpilchak, M. B., Cherniavskiy, M. V., Tokariuk, A. I., Oleksiv, T. M., Tymchuk, Y. Y., Solomakha, V. A., Solomakha, T. D., \& Mayor, R. V., 2006. Nature reserve Gorgany. Plant world. Kyiv: Phytosociocenter. (In Ukrainian)

Kobiv, Y. (2018). Trends in population size of rare plant species in the alpine habitats of the Ukrainian Carpathians under climate change. Diversity, 10(3), 62. https://doi.org/10.3390/d10030062

Kozurak, A. V., Antosiak, T. N., \& Voloshchuk, M. I. (2017). Regionally rare species of plants and habitats of CBR. Nature of the Carpathians: Annual Scientific Journal of CBR and the Institute of Ecology of the Carpathians NAS of Ukraine, 1, 17-27. (In Ukrainian) 
Kricsfalusy, V. V., \& Budnikov, G. B., (2003). Rare vascular plant species in the Ukrainian Carpathians. Proceedings of the Shevchenko Scientific Society, 12, 182-191. (In Ukrainian)

Kyyak, V., Shtupun, V., \& Bilonoha, V. (2016). Climatic threats to population of rare and endemic plants in upper part of the Ukrainian Carpathians. Visnyk of the Lviv University. Series Biology, 74, 104-115. (In Ukrainian)

Maldonado, C., Molina, C. I., Zizka, A., Persson, C., Taylor, C. M., Albán, J., Chilquillo, E., Rønsted, N., \& Antonelli, A. (2015). Species diversity and distribution in the era of Big Data. Global Ecology and Biogeography, 24, 973-984. https://doi. org/10.1111/geb.12326

Malynovskiy, A. K. (1991). Montane element in flora of Ukrainian Carpathians. Kyiv: Naukova Dumka. (In Russian)

Misiak, T. (2016). Nieznane stanowiska tojadu mołdawskiego (Aconitum moldavicum Hacq.) na Pogórzu Przemyskim. Rocznik Przemyski, 50, 41-46.

Mitka, J. (2003). The genus Aconitum L. (Ranunculaceae) in Poland and adjacent countries: A pheneticgeographic study. Cracow: Institute of Botany of the Jagellonian University.

Mitka, J. (2008). Aconitum moldavicum Hacq. (Ranunculaceae) and its hybrids in the Carpathians and adjacent regions. Roczniki Bieszczadzkie, 16, 233-252.

Mitka, J., Boroń, P., \& Sutkowska, A. (2013). Holocene history of Aconitum in the Polish Western Carpathians and adjacent regions: longdistance migrations or cryptic refugia? Modern Phytomorphology, 3, 9-18. http://doi.org/10.5281/ zenodo.161587

Mitka, J., \& Kozioł, M. (2009). Aconitum moldavicum (Ranunculaceae) on the Małopolska Upland. Fragmenta Floristica et Geobotanica Polonica, 16(1), 7-25.

Mráz, P., Barabas, D., Lengyelová, L., Turis, P., Schmotzer, A., Janišová, M., \& Ronikier, M. (2016). Vascular plant endemism in the Western Carpathians: Spatial patterns, environmental correlates and taxon traits. Biological Journal of the Linnean Society, 119(3), 630-648. https://doi. org/10.1111/bij.12792

Novikoff, A. V. (2009). Dependence of inflorescence structure of $A$. variegatum L. (Ranunculaceae) from elevation. Nature Almanac, Ser. Biol., 12, 147156. (In Ukrainian)

Novikoff, A. V. (2016). Monkshoods of Chornohora. Lviv: Liga-Press. (In Ukrainian)

Novikoff, A. V., \& Hurdu, B.-I. (2015). A critical list of endemic vascular plants in the Ukrainian Carpathians. Contribuţii Botanice, 50, 43-91.
Novikoff, A. V., \& Mitka, J. (2011). Taxonomy and ecology of the genus Aconitum L. in the Ukrainian Carpathians. Wulfenia, 18, 37-61. Retrieved from https://www.zobodat.at/pdf/ Wulfenia_18_0037-0061.pdf

Novikoff, A., Mitka, J., Kuzyarin, A., Orlov, O., \& Ragulina, M. (2016). Some notes on the genus Aconitum in Chornohora Mts. Modern Phytomorphology, 9(Suppl.), 35-73. https://doi. org/10.5281/zenodo.159703

Novikov, A. (2017). Genus Aconitum in Slovakia: a phenetic approach. Modern Phytomorphology, 11, 51-89. http://doi.org/10.5281/ zenodo.834040

Novikov, A., \& Hurdu, B. I. (2017, 28-30September). Geomorphologic division of the Ukrainian Carpathians for routine use in biogeography. In Proc. of the Second Interdisciplinary Symposium "Biogeography of the Carpathians: Ecological and evolutionary facets of biodiversity". Studia Universitatis Babeş-Bolyai, Biologia, 62(Sp. Iss.), 172-173.

Passos, F. G. O., \& Rebello, V. E. F. (2016). An autonomic parallel strategy for the projection of ecological niche models in heterogeneous computational environments. In P. F. Dutot, \& D. Trystram (Eds.), Euro-Par 2016: Parallel processing. Lecture Notes in Computer Science. Vol. 9833 (pp. 363-375). Cham: Springer. https://doi. org/10.1007/978-3-319-43659-3_27

Pawłowski, B. (1970). Remarques sur l'endémisme dans la flore des Alpes et des Carpates. Vegetatio, 21, 181-243. https://doi.org/10.1007/ BF02269663

Phillips, S. J., Anderson, R. P., \& Schapire, R. E. (2006). Maximum entropy modelling of species geographic distributions. Ecological Modelling, 190, 231-259. https://doi.org/10.1016/j. ecolmodel.2005.03.026

Phillips, S.J., \& Dudík, M. (2008). Modeling of species distributions with Maxent: New extensions and a comprehensive evaluation. Ecography, 31, 161-175. https://doi.org/10.1111/j.09067590.2008.5203.x

Piękoś-Mirkowa, H., \& Mirek, Z. (2009). Distribution patterns and habitats of endemic vascular plants in the Polish Carpathians. Acta Societatis Botanicorum Poloniae, 78(4), 321-326. https://doi. org/10.5586/asbp.2009.042

QGIS Development Team. (2020). QGIS Geographic Information System. Open Source Geospatial Foundation Project. Retrieved from http://qgis. osgeo.org

Scott, B., \& Smith, V. (2014). NHM DataPortal. Retrieved from https://data.nhm.ac.uk/ 
Singh, K. N., Lal, B., Singh, R. D., Todaria, N. P., \& Ahuja, P. S. (2007). Species richness, distribution pattern and conservation status of higher plants in the Spiti cold desert of trans-Himalaya, India. International Journal of Biodiversity Science \& Management, 3(4), 223233. https://doi.org/10.1080/17451590709618176

Stockwell, D. R. B., \& Peterson, A. T. (2002). Effects of sample size on accuracy of species distribution models. Ecological Modelling, 148(1), 1-13. https:// doi.org/10.1016/S0304-3800(01)00388-X

Subedi, S. C., Bhattarai, K. R., \& Chauudhary, R. P. (2015). Distribution pattern of vascular plant species of mountains in Nepal and their fate against global warming. Journal of Mountain Science, 12, 1345-1354. https://doi.org/10.1007/ s11629-015-3495-9

Sutkowska, A., Boroń, P., \& Mitka, M. (2013). Natural hybrid zone of Aconitum species in the Western Carpathians: Linnaean taxonomy and ISSR fingerprinting. Acta Biologica Cracoviensia. Ser. Botanica, 55(1), 114-126. https://doi.org/10.2478/ abcsb-2013-00015

Szafer, W. (1930). The mountain element in the flora of the Polish Plain. Rozprawy Wydziału MatematycznoPrzyrodniczego, PAU, Seria 3, Dział B, 69, 83-196.

Tapia-Silva, F. O., Hernández-Cervantes, O. E., VilchisAlfaro, M. I., Sentíes, A., \& Dreckmann, K. (2015, 11-15 May). Mapping of algae richness using spatial data interpolation. In 36th International symposium on remote sensing of environment, Berlin, Germany. International Archives of the Photogrammetry, Remote Sensing and Spatial Information Sciences, XL-7/W3, 1005-1008. https://doi.org/10.5194/isprsarchivesXL-7-W3-1005-2015

Tasenkevich, L. O. (2003). Vascular plants flora diversity of the Ukrainian Carpathians. Proceedings of Taras Shevchenko Scientific Society. Ecological Issue, 12, 147-157. (In Ukrainian)

Tasenkevich, L. O. (2014). Endemism of the Carpathian's flora - Ecological and chorological pecularities. Proceedings of Taras Shevchenko Scientific Society. Ecological Issue, 39, 22-36. (In Ukrainian)

Thiel-Egenter, C., Gugerli, F., Alvarez, N., Brodbeck, S., Cieślak, E., Colli, L., Englisch, T., Gaudeul, M., Gielly, L., Korbecka, G., Negrini, R., Paun, O., Pellecchia, M., Rioux, D., Ronikier, M., Schönswetter, P., Schüpfer, F., Taberlet, P., Tribsch, A., ... the IntraBioDiv Consortium. (2009). Effects of species traits on the genetic diversity of high-mountain plants: a multi-species study across the Alps and the Carpathians. Global Ecology and Biogeography, 18, 78-87. https://doi. org/10.1111/j.1466-8238.2008.00421.x
Tsaryk, J. V., Kyyak, V. G., Kobiv, Y. J., Dmytrakh, R. I., Danylyk, I. M., \& Nesteruk, Y.J. (2003). Intra- and interpopulation diversity of some rare, endemic and relic plant species of the Carpathians. Scientific Proceedings of the Forestry Academy of Sciences of Ukraine, 2, 103107. (In Ukrainian)

Tzvelev, N. N. (2001). Genus 9. Borets - Aconitum L. In N. N. Tzvelev (Ed.), Flora of Eastern Europe. Vol. 10 (pp. 55-66). Saint Petersburg: Mir i Sem'ya. (In Russian)

Utelli, A.-B., Roy, B. A., \& Baltisberger M. (1999). History can be more important than "pollination syndrome" in determining the genetic structure of plant populations: the case of Aconitum lycoctonum (Ranunculaceae). Heredity, 80, 574-584. https://doi.org/10.1038/ sj.hdy.6885070

Utelli, A.-B., Roy, B. A., \& Baltisberger, M. (2000). Molecular and morphological analyses of European Aconitum species (Ranunculaceae). Plant Systematics and Evolution, 224, 195-212. https://doi.org/10.1007/BF00986343

Vetaas, O. R., \& Grytnes, J.-A. (2002). Distribution of vascular plant species richness and endemic richness along the Himalayan elevation gradient in Nepal. Global Ecology and Biogeography, 11, 291-301. https://doi.org/10.1046/j.1466822X.2002.00297.X

Wang, G., Zhou, G., Yang, L., \& Li, Z. (2003). Distribution, species diversity and life-form spectra of plant communities along an altitudinal gradient in the northern slopes of Qilianshan Mountains, Gansu, China. Plant Ecology, 165, 169-181. https://doi. org/10.1023/A:1022236115186

Wissjulina, O. D. (1953). Genus 299. Akonit Aconitum L. In M. V. Klokov, \& O. D. Wissjulina (Eds.), Flora of UkrSSR. Vol. 5 (pp. 56-70). Kyiv: Publishing House of the Academy of Sciences of UkrSSR. (In Ukrainian)

Williams, N., Stewart, A., \& Papadopoulos, P. (2017). Virtualizing Lifemapper software infrastructure for biodiversity expedition. Concurrency and Computation: Practice and Experience, 29, e4137. https://doi.org/10.1002/cpe.4137

Zając, M. (1996). Mountain vascular plants in the Polish lowlands. Polish Botanical Studies, 11, 1-92.

Zapałowicz, H. (1908). Conspectus Florae Galiciae criticus. Vol. 2. Kraków: Nakładem Akademii Umiejętności 


\title{
Просторовий аналіз та моделювання поширення Aconitum moldavicum в Українських Карпатах та на прилеглих територіях з наголосом на використані алгоритми
}

\author{
А. Новіков ${ }^{1,2}$, Ю. Мітка ${ }^{3}$
}

${ }^{1}$ Відділ біосистематики та еволюції, Державний природознавчий музей НАНУкраїни, вул. Театральна, 18, Львів, 79008, Україна

${ }^{2}$ Кафедра ботаніки Львівського національного університету імені Івана Франка, вул. Грушевського, 4, Львів, 79004, Україна; novikoffav@gmail.com

3 Інститут Ботаніки Ягеллонського університету, Ботанічний сад Ягеллонського університету, вул. Коперника, 27, Краків, 31501, Польща; j.mitka@uj.edu.pl

Стаття має на меті представити всебічний аналіз всіх доступних даних (включаючи гербарні збори, опубліковані відомості та бази даних) щодо поширення Aconitum moldavicum в Українських Карпатах з метою побудови карт, що моделюють поширення цього виду в регіоні та на прилеглих територіях.

Aconitum moldavicum - це карпатський субендемік, що широко розповсюджений по території усіх Карпат і частково виходить за межі гірського масиву на прилеглі рівнинні території. Цікаво, що A. moldavicum є доволі рідкісним для Закарпатської рівнини, де він спорадично представлений виключно підвидом A. moldavicum subsp. hosteanum. Цікаво також, що інший підвид, A. moldavicum subsp. moldavicum, представлений на Вигорлат-Гутинському масиві виключно на Вигорлатських горах поблизу кордону зі Словаччиною і більше ніде в межах масиву не трапляється. Водночас, обидва підвиди доволі часто трапляються на Прикарпатті та Волино-Подільській височині разом 3 їхнім гібридом A. moldavicum nothosubsp. confusum.

Інші два гібриди, A. moldavicum nothosubsp. porcii та nothosubsp. simonkaianum підтверджено в Українських Карпатах виключно для регіону Мармароських гір. Ймовірно, A. moldavicum nothosubsp. porcii може бути також віднайдений на Чорногорі. Водночас, присутність A. moldavicum nothosubsp. simonkaianum на Волино-Поділлі $\epsilon$ сумнівною, оскільки немає жодного іншого підтвердження окрім єдиного зразка, що зберігається у гербарії GJO. Більше того, інші зразки зібрані Б. Блоцьким з того самого регіону виявилися такими, що належать більш тривіальному підвиду A. moldavicum nothosubsp. hosteanum.

Ми використали різні алгоритми SDM аналізу (MaXent, BioClim, GARP, EnvDist, TIN та IDW) з метою виявити алгоритм, що найбільш точно відповідає реальному поширенню A. moldavicum на даній території. BioClim доволі точно вказав на центри поширення виду в Карпатах, на Волино-Подільській височині, а також Польській рівнині. В той час, як традиційно прийнятий алгоритм MaxEnt недооцінив ймовірність поширення виду на територіях з підтвердженою присутністю і навпаки переоцінив - на територіях, для яких вид невідомий. IDW алгоритм продемонстрував подібні до MaXent результати і підтвердив можливість використання з метою моделювання поширення видів. 